\title{
CONSEQUENTIAL APPROACH OF ISLAMIC BIOETHICS
}

\author{
Arif Hossain \\ Vice President, Bangladesh Bioethics Society
}

\begin{abstract}
Bioethics is the understanding of right, responsibility, justices and moral interaction in living being. It is the corner stone to guide the society for righteous action. Due to the enormous innovation of sciences and technology, wide-ranging ethical issues have been raised in biotechnology, nanotechnology, assisted reproductive technologies (ART) and stem cell research. These advancements could lead to irreversible disasters if not limited by ethical principles and similarly society can not gain the benefit from this new technology if not addressed by the philosophical reflection. To date few attempts appear to have been made at a critical interpretation of the philosophical reflection on Islamic bioethics. This article shows that the Islamic medical ethics is a virtue ethics, deontological ethics (moral duties and obligations) and a consequential approach. It may help the health professionals, educator and the policy maker to get insight the knowledge of new application of ART in their practice for the welfare of the society.
\end{abstract}

\section{Key words: Consequential approach and Islamic bioethics}

HISTORICAL BACKGROUND OF ISLAMIC MEDICAL ETHICS: The Code of Hammurabi in Babylonian may the first clearly outlined medical code for the controlled medical malpractice. In 1790 B.C, the most famous Mesopotamian law, "Codex Hammurabi" that attempted to regulate medicine and to protect patient's rights. The Codex Hammurabi described "If a surgeon performs a major operation on a nobleman with a bronze lancet and caused the death of this man, they shall cut off his hands" (Halwani and Takrouri, 2007). The code is engraved on a slate which is kept at the Louvre museum in Paris. Persian history says that the Sassanian encyclopaedic (Dinkard) and Zoroastrian's holy book (Vendidad of the Avesta) have mentioned the characteristics of a good physician (Zahidi et al 2009). During late $600 \mathrm{AD}$ the Qur'an and the traditions of the Prophet have laid down detailed and specific ethical guidelines regarding various medical issues. Consequently, Muslim physicians paid special attention to ethics in their professional practice (Daar and Khitamy 2001). In 807-861 AD, a number of books related to medical ethics have been written to guild the physician in their practice e.g. Spiritual Medicine (Teb e Rohani), Ethics of a physician (Adab al-Tabib), the Paradise of Wisdom (Ferdous al Hekmat) and the Perfect Art of Medicine (Kamel al-sanaatal-Tibbia). In 931 A.D. the Caliph Al-Mugtadir from the Abbasid dynasty, ordered the Chief Court-Physician Sinan Ibn-Thabit to screen the 860 physicians of Baghdad and only those qualified were granted license to practice (al-Ghazal, 2004 cited in Waber 2010).

ISALMIC BIOETHICS: Islamic jurists pronounce opinions align to biomedical innovations based on Shari'ah- (Quran, Hadit, ijma and qiyas). Islam put a great emphasis on moral virtues, and the completion and perfection of moral ethics. The widely applied principle of Shari'ah law la darar wa la dirar (there shall be no harm inflicted or reciprocated) which similarity in basic principles can be seen in Hippocrates' dictum Primum non nocere (first do no harm). Finally if these four sources do not answer the question, it invokes the principle of maslaha (public benefit) by ijtehad (Fadle 2002).

Islamic bioethics is based on duties and obligations (e.g. to preserve life, seek treatment, rights of community and the individual) do feature in bioethics, as does a call to virtue (Ihsan) (Daar and Khitamy 2001). Ali bin Sahl Rabban at-Tabari (died 855) wrote in his "The Paradise of Wisdom in Medicine", the five qualities of medical ethics, e.g. first continuous care, second battle with illness, 
third respect for kings and the common people agreement and respect to their skill, fifth name of God (Waber 2012). Similarly, Al-Ruhawi in his "Ethics of a physician" stated "train by employing good morals and actions with sympathy, mercy, gentleness, chastity, courage, generosity, justice. Do not aim for an excess of worldly riches (Waber 2010).

Aristotle is concerned with social relations and his ethical approach is characterized as a virtue ethics e.g. how do goods such as friendship, pleasure, honor and wealth contribute to a good or virtuous life (Waber 2010). Islam has a tradition of professional medical ethics Adab (etique) or Akhlaq (ethics) which is both analogous and historically related to Aristotelian virtue ethics (Waber 2010). Thus, many moral dilemmas or moral problems in medical praxis can be solved, or will never arise, simply by visiting a virtuous physician as outlined in the Islamic virtue ethics tradition.

In Islam, rights are coupled with responsibilities and the collective rights of the society (maslahah alummah). Communitarian right must always be given priority over individual rights (Zawawi 2012). Therefore, in the Muslim context, the primacy appears reserved for the principle of public benefit (maslaha) and the principle of justice as the collective interest takes precedence over that of the individual autonomy (Daar and Khitamy 2001). Furthermore, the family often remains the important subject for the patient's decisions in relations with the doctor. Families and the male guardians expect to be part of the medical decision making process. Therefore, family concerns can take precedence over autonomy of patient to medical decision-making about their own bodies. This can be a limit to the patient's autonomy (Atighetchi 2007).

Another important principles of Islamic bioethics are necessity (Darura), public benefit (Maslaha), local custom (urf) and justice (Atighechti 2007, Daar and Khitamy 2001). Principle of Maslaha (public benefit) is consequentialist ethics. Abdulaziz Sachedina provides the following case illustrating the use of consequentialist ethical reasoning in Islam: A Muslim before dying has swallowed a valuable object belonging to a Muslim orphan. Is it permissible to dissect the cadaver to retrieve the object? Many jurists have said 'yes' because of the consequences. The swallowed object may form part of the orphan's inheritance. The consequences to the orphan, the loss of his right to his inheritance, outweigh the foundational Islamic moral principle of not violating the dignity of the dead The rights of orphans, the subject of several passages in the Qur'an, form a strong concern in Islam, undoubtedly because Prophet Muhammed himself was an orphan and knew that they needed special protections (Sachedina, 2009).

In Islam New medical technologies, such as ART is employed by consequential arguments with weighing the public benefit by necessity. Infertility is believed as a disease and desire for a cure in principle by means of ART due to the importance of family. A basic tenet of Islam is that prohibited actions, if performed out of necessity, become permissible even it violet the primary source. As for example, the majority of scholars declared collection of sperm for artificial insemination is through masturbation is prohibited as Qur'an mentions

[the successful believers] who abstain from sex, except with those joined to them in the marriage bond, or (the captives) whom their right hands possess, for (in their case) they are free from blame, but those whose desires exceed those limits are transgressors ... (Qur'an, Sura al- Muminul 23: 5-7).

However, masturbation is permitted by public interest with condition that it can be done in order to collect sperm for artificial insemination of husband (AlH) within the marriage bond and in disease condition. AlH does not create any ethical problem vis a vis Islamic guidelines (Sharmin 2007).

In the case of absolute necessity, where religiously lawful alternatives do not exist, Islamic teaching allows for sacred law to be suspended, temporarily if possible. The use of pork insulin and heart 
valves from pigs has been ruled on the basis of this principle of necessity, when consumption of pork is forbidden by Qur'an (Gatrad and Sheikh 2001).

Maslaha appears to have points in common with Bentham's principle of utility or aggregate good. Bentham's (1748-1832) philosophy of Utilitarianism forms the basis of health care economics (costbenefit, cost effectiveness analyses). A utilitarian action is good to the extent that it maximizes aggregate utility (benefits) to the community. On an individual level, utility can be measured by feelings of pleasure and pain. A good act is one that maximizes pleasure, and minimizes pain.

But in Islamic medical ethics a pragmatic (utilitarian) argument will never take precedence over a clearly articulated principle originating in the Qur'an. New medical technologies, such as ART is employed by consequential arguments with weighing the benefits to society by necessity in Islam. In instance, infertility is believed as a disease and desire for a cure in principle supportive of ART due to the importance of family. But has forbidden certain ART such as surrogate motherhood as well as sperm and ova donations between non-related donors because this violates the injunction of mixing lineages (nasab) and therefore would technically result in adultery or fornication (zina) (Islamic Medical Association of North America, 2005).

CONCLUSION: Therefore, Islamic medical ethics is a virtue ethics, deontological ethics established on foundational moral duties and obligations and a consequential approach. To date few attempts appear to have been made at a critical interpretation of the philosophical reflection on Islamic bioethics. Due to the rapid advancement of science and technology society can gain the benefit from this new technology if the ethical principles are correctly addressed.

\section{REFERENCES:}

1. Al Quran Sura Al Mu'minun 23, v. 5, 6, 7.

2. Atighetchi D. Problems of Islamic Bioethics and Biolaw. Derecho y Religion 2007; 2:221-229.

3. Daar SA and Khitamy ABA. Bioethics for clinicians: 21. Islamic bioethics. CMAJ 2001;164(1):60-63.

4. Fadel HE. The Islamic Viewpoint on new assisted reproductive technologies. Fordham Urban Law J 2002; 30(1):147-157.

5. Gatrad AR and Sheikh A.Medical ethics and Islam: principles and practice. Arch Dis Child 2001; 84:72-75.

6. Islamic Medical Association of North America (IMANA). Islamic medical ethics: The IMANA perspective 2005. http://www.imana.org/ethics.html. (Accessed on April 2012).

7. Halwani, T., M. Takrouri.. Medical laws and ethics of Babylon as read in Hammurabi's code (History). The Internet Journal of Law, Healthcare and Ethics 2007; 2:4.

8. Sharmin I, Rusli BN, Rani A and Hanapi BMN. Ethics of artificial insemination: An Islamic prospect. JIMA 2007; 39: 29-32.

9. Sachedina AA. Islamic biomedical ethics: Principles and applications. Oxford: Oxford UP. 2009 
10. Weber AS. Bioethical reasoning in Islam. Intern J of Arts and Science 2010; 3(15): 607-617.

11. Zahedi F, Razavi SHE and Larijani B. A two-decade review of medical ethics in Iran. J Publ Health 2009; 38 (Sup 1):40-46.

12. Zawawi M. Third party involvement in the reproductive process: comparative aspects of the legal and ethical approaches to surrogacy. Eubios Ethics Institute. http://Www.Eubios.Info/ABC4/Abc4389.htm (Accessed on May 01, 2012). 